\title{
BANKRUPTCY MODEL ANALYSIS: COMPARATIVE STUDIES BETWEEN SHARIA AND NON SHARIA MANUFACTURING COMPANIES
}

\author{
Ruhadi ${ }^{1}$, Muhamad Umar Mai ${ }^{2}$
}

\begin{abstract}
Bankruptcy Model Analysis: Comparative Studies Between Sharia and Non_Sharia Manufacturing Companies. This study aims to find out three important things: first is based on the analysis of three bankruptcy models that Altman, Springate and Zmijewsky, which is the most accurate in predicting the potential bankruptcy of sharia and non sharia, secondly based on the most accurate model, whether sharia companies have a potential bankruptcy smaller than non_sharia. Analysis of variance, it was found that the most accurate model in predicting potential bankruptcy is Altman $Z_{-}$score. Based on this model could be found, statistically significant that a group of sharia has a potential bankruptcy smaller than the non_sharia. Based on the third question, could be found that good corporate governance have positive and significant effect to potential bankcruptcy for the sharia companies, while the rate exchange of rupiah to US dollar has negative and significant effect to ones.
\end{abstract}

Keywords: bankcrupty model; sharia companies; non-sharia companies.

\begin{abstract}
Abstrak. Analisis Model Kebangkrutan: Studi Perbandingan Antara Perusabaan Manufaktur Syariab dan Non Syariab. Penelitian ini bertujuan mengungkap 3 halpentingyaitupertama berdasarkan analisis 3 modelkebangkrutan yaitu Altman, Springate dan Zmijewsky, mana yang paling akurat dalam memprediksi potensi kebangkrutan kelompok perusahaan manufaktur syariah dan non shariah, kedua berdasarkan analisis model yang paling akurat tersebut, apakah benar bahwa kelompok syariah memiliki potensi kebangkrutan yang lebih kecil dari kelompok non_syariah. Pengujian beda dua rata-rata ditemukan bahwa model yang paling akurat dalam memprediksi kelompok perusahaan manufaktur di BEI adalah Altman $Z$ score dan berdasarkan model ini ditemukan, secara statistik signifikan bahwa kelompok syariah memiliki potensi kebangkrutan yang lebih kecil dibanding dengan kelompok perusahaan non_syariah. Merujuk pada pertanyaan ketiga, dapat ditemukan bahwa ada pengaruh positif dan signifikan dari good corporate governance dan pengaruh negatif dan signifikan dari nilai tukar rupiah terhadap US dolar terhadap potensi kebangkrutan untuk kelompok syariah.
\end{abstract}

Kata kunci: Model kebangkrutan, kelompok perusahaan syariah dan non_syariah 


\section{Introduction}

One of the objective in doing business is how to earn the optimal profit that could guarantee the firm to be growth and survival (Salvatore, 2015), where it finally would improve the firm value. The firm value also means increase in shareholders wealth. Unfortunately, the failed companies are the fenomenon that occured frequently in the business area (Fachrudin, 2008). Many factors could cause company bankcrupt, but in general its can be devide into two categories, those are: internal and external factors (Darsono and Ashari, 2005). Internal factors include: inefficient of the management, capital structure with liabilities dominant, and moral hazard. The external factors like; customer taste, economic condition that could not be anticipated by the management (Veronica, et.al, 2014). Based on the US data of companies failures, there are nine biggest corporates collaps for the last 10 years, caused by some factors. The Table 1 repressent 5 biggest corporation was failed in USA, UK dan Japan.

Table 1-List of failed corporation

\begin{tabular}{clll}
\hline NO. & \multicolumn{1}{c}{ CORPORATION } & \multicolumn{1}{c}{ BUSINESS AREA } & \multicolumn{1}{c}{ YEAR } \\
\hline 1 & Lehman Brothers Holdings & Financial Institution; US\$ 691 Billion & September 2008 \\
& USA & & \\
2 & Pilpa - Prench & Ice cream and Candy producent & September 2012 \\
3 & General Motors & Automotive Company & Jun 2009 \\
& USA & Assets: US\$ 91 Billion & \\
4 & Global Energy Japan Co. Ltd. & Electricity Solar System & May 2014 \\
5 & $\begin{array}{l}\text { Thomas Cook Group } \\
\text { London UK }\end{array}$ & Tourism Company & October 2013 \\
\hline
\end{tabular}

Source: Tempo.Co, Business, Saturday, November 22, 2014

Corporate failure fenomenon in Indonesia also occured frequently, at least 37 companies was suppossed as a strong corporation like some of the biggest Bank in the Suharto's regime also go to be liquidated at 1999, cause of the having great financial problem (Tempo Interaktif: November 2014). Table 2 show 7 of the biggest companies in Indonesia go to the financial distress and bankcrupt. Financial failure occur when liabilities much more than amount of the normal asset or when current liabilities more than current asset (Elmabrok, et al., 2012). The bankcruptcy would bring bad impact to the world economic (Li, 2012), include to the investors, creditors, management and labor. Therefore all of the stakeholders need to know the 
indicators related to the source of companies bankcruptcies, in order to anticipate and could escape from the lost of their assets (Kewal, 2012).

Table 2-List of failed Corporation in Indonesia

\begin{tabular}{clll}
\hline NO. & \multicolumn{1}{c}{ CORPORATION } & BUSINESS AREA & \multicolumn{1}{c}{ YEAR } \\
\hline 1 & Kretek PT HM Sampoerna & Cigarrette & June, 2014 \\
2 & Industri Genteng Plered & Cerramics & June, 2010 \\
3 & Batavia Air & Air plane & January 2013 \\
4 & Bouraq Indonesia & Air plane & Desember 2004 \\
5 & Perusahaan Daerah Perkebunan Kahyangan & Plantation & July 2014 \\
6 & Elpida Memory Inc & Computer chips & February 2012 \\
7 & PT BPR Arthasraya Sejahtera & Banking & May, 2014 \\
\hline
\end{tabular}

Sources: Tempo.Co, bisnis: Saturday, November 22, 2014

The methods for detect the bankcruptcies potentcy has been found by some expertises likes: Altman Z-score 19968, Springate Model 1978, Zmijeski Model 1983, James A. Ohlson 1980, Grover's Model 2001. Several of the Models analysis showed the differencies result in detect bankcruptcies potentcy like: Fatmawati (2012) showed that the Zmijewski is the accurate prediction models much more than Altman Z-Score and Springate. Hadi and Angggraini (2008) conclude that Altman Models is not the best predictors if its compared to the others third predictors. Imanzadeh et al. (2011) has proven that Springate model much more conservative than Zmijewski. Among expertists do not agree to the result of the research about sources of the financial distress that would bring the companies go to failed (see Paranowo, 2010; Glezakos, et.al., 2010; Abdullah, et.al, 2008; Haber J.R, 2005; Titman dan Opler, 1994). Since sharia economic be initiated 1992 in Indonesia, sharia financial institution has grown rapidly, at least 3000 offices with 18 million customers and asset total Rp. 240 billion has achieved (Kompas. Com, November 5, 2014). Sharia financial product like; reksa dana and sharia bond has been increase and july of 2000, BEI launching Jakarta Islamic Index (JII). JII and list of sharia securities, one of the Index that cover sharia criteria. This index give the favourable investment alternatives and save for investors. public companies which listed in JII tend to have lower bankcruptcy level, althought when Indonesia in the crisis era.

Novelties of this research would be explined that several previous studies about the company more partial defaults, which are as follows: First, Analyzing the 
potential bankruptcy of the company using only one method (Wang and Campbell, 2010); Second, analyzing the potential bankruptcy of companies use two or more methods, to determine the best method; Third, analyzes the factors that influence the potential bankruptcy of the company by simply involving the company's fundamentals (Salehi and Abedini, 2009; Paranowo, 2010); and Fourth, analyzes the factors that influence the potential bankruptcy of the company involves macroeconomic indicators and the company's fundamentals (Veronica, et.al., 2014). This study differs from previous studies: First, involves two distinct groups of companies, Sharia and non_sharia. Second, this study involves three concepts of variables as factors that influence the potential bankruptcy include are: financial performance indicators, macro economic indicators, , and good corporate governance indicators.

Based on background above, this research be intended to do examination of bankcruptcy potentcy for both the group, using Altman Z score, Springate and Zmijewski. Analysing factors that influence to the bankcruptcy by involving macro economic indicators; financial performance indicators; and multiple regression analysis would be used as the methods in detect bankcruptcy potencial for each group of company.

The purpose of this study is to resolve or answer the formulation of the problems outlined in the above question as follows: First, to identify bankruptcy prediction model, which is the most accurate of the three models; Altman, Springate and Zmijewski. Second, by using the most accurate models are expected to be found which has the less potential bankruptcy between sharia and non sharia.Third, which factors those are financial performance indicators, corporate governance indicators and macro economic indicators that infuence to the potential bankcruptcy for both group of the companies.

\section{Literature Review}

Financial disstres is a condition that describes companies that are experiencing financial difficulties, meaning that the company in a position not safe from the threat bankruptcy. The bankruptcy of the company is characterized by a decrease in financial conditions that occur continuously. The conditions are most easily seen from the company experiencing financial disstres is a violation of debt payment commitments accompanied by the termination of the payment of dividends. The financial distress caused by a series of fail in decision-making and a lack of supervision of the financial management of the company (Brigham and Daves, 2003). This gives the conclusion that there are no guarantees for large companies avoid these issues, because of financial distress related to finance which each company must deal with the finances to maintain continuity of operations (Imanzadeh et al., 2011). 
The sources of bankruptcy can be derived from the internal and external factors. Internal factors such as lack of management experience, lack of knowledge in the use of assets and liabilities effectively. While external factors include; inflation, tax and legal systems, the depreciation of foreign currencies, and other reasons. The causes of financial distress of the company is more micro, among the factors are (Damodaran, 2011): First, difficulty cash flow. This occurs when revenue are not sufficient to cover operating expenses, cause of the company operating activities. Second, the amount of debt. Debt collection policy to cover the company's operations costs to pay interest charges periodically and restore the principal debt in the future. Third, the losses for several years. The operating loss experienced by the company would lead to a negative cash flow. Although the company can overcome the three things above, not necessarily the company can avoid financial distress, because there are external factors that cause financial distress. The external factors that can lead to financial distress is the macro economic nature.

Corporate governance as a set of mechanisms that will protect investors against dangerous stunt performed by people within the company to the capital that they invested in the company. The basic principles of good corporate governance contained in the general guidelines of good corporate governance Indonesia, can be expressed as follows: First, transparency, the company must provide information, relevant, accessible and understood by stakeholders; Second, accountability, companies must be accountable for performance in a transparent and fair; Third, responsibility, the company must comply with the legislation and to implement responsibilities towards society and the environment; Fourth, independency, the company is managed independently without any conflict of interest and influence management that do not fit the principles of healthy corporate; Fifth, fairness, companies must pay attention to the interests of shareholders and other stakeholders based on the principles of fairness and equality.

Referring to the above description, it would require a structure and a mechanism to ensure the implementation of the five basic principles of the good corporate governance. Some indicators are often used as a proxy of good corporate governance can be summarized as follows (Argüden, 2013): First, the shareholding structure; Second, the proportion of independent board members; and Third, size of the board directors.

Financial performance is the determination of the measures that can identify the success of a company in generating profits. The financial performance is the company's ability to manage and control its resources. Thus, the financial performance is the achievement of management, particularly financial management in achieving the company's profit in order to maximize the frm's value and the level 
of shareholder wealth. The measurement of performance of public companies is a difficult concept, both in definition and measurement, because as a multidimensional construct performance (Ghosh, 2013). Assessment using a single measurement dimension is not able to provide a comprehensive understanding. Therefore, the measurement of financial performance should be using or integrating the diverse dimensions of measurement.

Financial ratio analysis is a common method used to measure the performance of companies in the financial sector. The ratio is a tool that compares one thing with the other so as to show the relationship of a financial statement of the balance sheet and income statement. There are several motivations to examine the data in the form of ratios, (Wang and Campbell, 2010): First, attempt to control the effect of the difference in size between the companies for some time; Second, to make the data in satisfying the assumptions underlying the statistical analysis tools, such as regression analysis; Third, test a theory in which the ratio is the variable of interest; Fourth, utilizes the empirical nature of collisions that can be observed between financial ratios and estimates or predictions of some variables of interest.

The financial statements like; balance sheet, income statement and cashflows statement have not been able to provide maximum benefits to the users, before it is processed in the form of a ratio (Wang and Campbell, 2010). Thus, studies using secondary data from the financial statements, have not been optimally provide the indicator overall usefullness of the information contained in the financial statements as financial accounting information system products.

Macroeconomic conditions in an environment that may affect the company's operations. The investor's ability to understand and predict the macro-economic conditions in the future, will be very useful in making profitable investment decisions. Macro-economic indicators are often linked to capital markets, interest rate fluctuations, inflation and exchange rate. In theory, between the interest rate and financial performance and the company's stock price has a negative relationship. The high interest rates will affect the present value of the cash flow of the company, so that investment opportunities will not be as attractive anymore. The high interest rates also will increase costs of capital for the company and lead to the return required by investors will increase. The high inflation rate is usually associated with economic conditions that are too hot (over-heated). That is, the economic conditions experienced in demand for products that exceed the capacity of product offerings, so prices tend to rise. Inflation is too high will cause a decrease in the purchasing power of money. In addition, high inflation can also reduce the level of real income obtained by investors from their investments. Exchange rate is a macroeconomic variables that influence the volatility of financial performance and 
stock price. The depreciation of the domestic currency will increase export volume. When the international market demand is quite elastic it will improve the cash flow of domestic companies, which then increases in stock prices, which is reflected in CPI (consumer price index). Conversely, if the issuer to buy domestic products, and has debt in the form of dollars, the company's performance and share price will fall. The depreciation of the exchange rate, in turn, would raise the stock price reflected on CPI in the economy experiencing inflation.

Instrument development of Islamic Capital Market in Indonesia began PT. Dana Reksa Investment Management (DRIM) launched the Jakarta Islamic Index (JII) which includes the stocks of issuers whose operations meet the category of sharia law. According to the DSN (Dewan Syariah Nasional or National Sharia Board) declaration, No.40/DSN-MUI/X/2003 Article 3, the category of stocks that are not included in the index of sharia, among others, the following: First, enterprises gambling and games are classified as gambling or trafficking of prohibited according to the word of God in QS. Al-Maidah \{5\}: 90-91; Second, Conventional financial institution (usury) including conventional banking and insurance in accordance with the word of God in QS. Al-Imron \{3\}: 130; Third, businesses that produce, distribute and trade food and drink that are unclean (haram); Fourth, businesses that produce, distribute or supply any goods or services that damage morale and haram.

\section{Method}

The population of this research is all manufacturing companies listed in Indonesia Stock Exchange. The population is divided into two categories: Sharia manufacturing company and non_sharia. Observation period between the years 2010-2014. Sampling using purposive sampling. Meanwhile, the company sample criteria used are: (1) to publish its financial statements as of 31 December 2005 to 2014; (2) meet the identified category sharia and non_sharia categories; (3) provided data on the percentage of shares held by other institutions; and (4) provided data on the number of board members and the number of independent board members.

The data used in this research is quantitative data, that is represented by a number that indicates the value of the variable. Meanwhile, the source of the data used is secondary data that is obtained from; (1) Indonesian Capital Directory Markers (ICMD), for publication in 2010 until 2014; (2) Annual report for all the companies selected as members of the sample, published from 2010 to 2014; (3) JSX Monthly Statistic, for publication in January 2010 until December 2014. 
This study uses three analysis of bankruptcy model, are: Altman Z-Score; Springate; and Zmijewski. These models are used to analyze the condition of the company, that divide into sharia companies manufacturing group and non_sharia group. Furthermore, bankruptcy model analysis, most appropriate (best) for each of the groups of companies were analyzed using Mean Square Error (MSE) of the indexs score calculated from each model used. To determine the most appropriatte model is to select the lower mean square error (MSE) from the accuratte models choosen.

\section{Altman Z_Score Model}

Altman found five types of financial ratios that can be combined to see the difference between a company that went bankrupt and were not bankrupt. Altman $\mathrm{Z}$-Score is determined using the following formula:

$$
\mathrm{Z} \_ \text {score }=0,012 X_{1}+0,014 X_{2}+0,033 X_{3}+0,006 X_{4}+0,999 X_{5}
$$

Description:

$X_{1}=$ Working Capital to Total Assets;

$X_{2}=$ Retained Earnings to Total Assets;

$X_{3}=$ Earnings Before Interest and Taxes to Total Assets;

$X_{4}=$ Market Value Equity toBook Value of Total Debt;

$X_{5}=$ Sales to Total Assets

Score classification result that used by Altman is: Score Z>2.99 healthy companies; Score $\mathrm{Z}<1.81$, the company classified the potential bankrupt; Score between 1.81 to 2.99 of companies classified in the gray area, the cut-off for this index is 2.675 .

\section{Springate Bankruptcy Model}

Springate models using step wise multiple discriminate analysis to pick 4 of 19 financial ratios and formulate a model of analysis, as follows:

$$
S=1.03 \mathrm{~A}+3.07 \mathrm{~B}+\mathbf{0 . 6 6} \mathrm{C}+\mathbf{0 . 4} \mathrm{D}
$$

Description:

A = Working Capital to Total Assets Ratio;

$B=$ Net Profit before Interest and Taxes to Total Assets Ratio;

$\mathrm{C}=$ Net Profit before Taxes to Current Liabilities;

$\mathrm{D}=$ Sales to Total Asset Ratio. 
Springate models have a standard which the company has a $Z$ score $>0,862$ classified healthy company, while the company has a $\mathrm{Z}$ score $<0,862$ classified as potentially bankrupt company.

\section{Zmijewski Bankruptcy Model}

Expansion of bankruptcy prediction studies conducted Zmijewski (1983). F-test indicator to the rate of return, liquidity, leverage, turnover, firm size, and stock return volatility, showed a significant difference between the company's healthy and unhealthy. The model developed Zmijewski is as follows:

$$
X=-4,3-4,5 X_{1}+5,7 X_{2}-0,004 X_{3}
$$

Where:

$\mathrm{X}_{1}=$ Earnings After Taxes to Total Assets Ratio;

$\mathrm{X}_{2}=$ Total Debt to Total Assets Ratio;

$\mathrm{X}_{3}=$ Current Assets to Current Liabilities Ratio

\section{Mean Paired Sample Test}

Paired sample z-test was used to test for differences in the analysis results of potential bankruptcy between sharia and non_sharia group of companies. This testing is done to identify whether the average potential bankruptcy of a sharia group lower than group of non_sharia.

\section{Determinants Analysis of Corporate Bankruptcy}

Based on the model of empirical research, it is known that the potential bankruptcy of the company was affected by the financial performance indicators, macro economic indicators and corporate governance indicators. Furthermore, financial performance indicators proxy for the four variables, namely: return on investment as; total asset turnover; current ratio; and debt to assets ratio. Macro economic indicators proxied by three variables: mean of inflation; the mean of the interest rate; and mean of exchange rates. Corporate governance indicators proxy for the four variables, namely: institutional ownership; size of board directors; independent boards; and managerial ownership.

$$
\begin{aligned}
\text { MTNS }= & \alpha+\beta_{1} \text { ROI }+\beta_{2} \text { TATO }+\beta_{3} C T R+\beta_{4} D A R+\beta_{5} M O I+\beta_{6} M I R+\beta_{7} M E R \\
& +\beta_{8} I N W N+\beta_{9} S O B D+\beta_{10} B I N D+\beta_{11} M G W N+\varepsilon \\
M T S Y= & \alpha+\beta_{1} R O I+\beta_{2} \text { TATO }+\beta_{3} C T R+\beta_{4} D A R+\beta_{5} M O I+\beta_{6} M I R+\beta_{7} M E R \\
& +\beta_{8} I N W N+\beta_{9} S O B D+\beta_{10} B I N D+\beta_{11} M G W N+\varepsilon
\end{aligned}
$$


Where:

MTNS $=$ Best Model For Non-Sharia group
MTSY $=$ Best Model For Sharia Group
ROI $=$ Return on Investment
CTR $=$ Current Ratio
MOI $=$ Mean of Inflantion
TATO = Total Asset Turn Over
DAR $=$ Debt to Asset Ratio
MER $=$ Mean of Exchange Rate
MIR $=$ Mean of Interest Rate
SOBD $=$ Size of Board of Directors
INWN $=$ Institutional Ownership
BIND $=$ Board Independent
MGWN = Managerial Ownership

\section{Result and Discussion}

Configuration data from this study can be described that overall the data is taken from the Indonesia Stock Exchange (ICMD), then ICMD taken only group of manufacturing companies and then categorized into two groups of companies are Sharia and Non_sharia. Data collected included the time span from 2010 to 2014 (5 years). In details, the year 2010 can be collected as many as 131 observations with details of companies manufacturing group sharia stock index 75 observations and 56 observation non_sharia index. In 2011 the same as in 2010, the year 2012 can be collected as many as 136 observations with details of group sharia stock index 105 observations and 31 observation group of non sharia index. 2013 can be collected as many as 137 observations with details of group sharia stock index 105 observations and 32 observation group of non_sharia index. 2014 can be collected as many as 135 observations with details of companies manufacturing group sharia 98 observations and 37 observation group of non_sharia index. Overall, therefore, the observation data in total is 670, in the span of 5 years from 2010 to 2014 with details of 458 sharia groups and 212 non_sharia groups.

Table 3, shows the score of each potential bankruptcy, drawn from 458 observational data for a sharia group manufacturing company. The first is the Altman model shows the average score of a potential bankruptcy at 1.6236 , while the lowest was -0.74 and the highest was 51.99 , this indication shows the range of 
numbers that is large enough 52.73 with a standard deviation of 3.86 . The second is Springate models, shows the average score of a potential bankruptcy at 1.2595, with a minimum value is -10.22 , maximum value is 13.64 and 23.87 range with standard deviation of 1.34. While the third is a model Zmijewski figures show the average score with a potential bankruptcy -2.1665 and -5.60 minimum value and the highest value is 17.61 and 23.21 as well as a range of values with standard deviation of 1.85 .

Table 3-Description Statistics Manufacturing Company Sharia Group

\begin{tabular}{cccccccccc}
\hline \multirow{2}{*}{ ISSI } & $\mathbf{N}$ & Range & Minimum & Max & \multicolumn{2}{c}{ Mean } & SD & Variance \\
\cline { 2 - 9 } & Statistic & Statistic & Statistic & Statistic & Statistic & Std. Error & Statistic & Statistic \\
\hline Altman & 458 & 52,73 &,- 74 & 51,99 & 1,6236 &, 18058 & 3,86464 & 14,935 \\
Springate & 458 & 23,87 & $-10,22$ & 13,64 & 1,2595 &, 06257 & 1,33905 & 1,793 \\
Zmijewski & 458 & 23,21 & $-5,60$ & 17,61 & $-2,1665$ &, 08655 & 1,85225 & 3,431 \\
Valid N & 458 & & & & & & & \\
(listwise) & & & & & & & & \\
\hline
\end{tabular}

Source: Processed from data

The following Table 4, shows the number of potential score bankruptcy for each models that taken from 212 observational data for a non_sharia group of manufacturing companies.

Table 4-Description Statistics Manufacturing Company Non_Sharia Group

\begin{tabular}{ccccccccc}
\hline \multirow{2}{*}{ NON_ISSI } & $\mathbf{N}$ & Range & Min. & Max. & \multicolumn{2}{c}{ Mean } & SD & Variance \\
\cline { 2 - 9 } & Statistic & Statistic & Statistic & Statistic & Statistic & SE & Statistic & Statistic \\
\hline Altman & 212 & 9,97 &, 00 & 9,97 & 1,0726 &, 06644 &, 96735 &, 936 \\
Springate & 212 & 38,93 & $-27,52$ & 11,41 &, 5856 &, 17834 & 2,59671 & 6,743 \\
Zmijewski & 212 & 30,06 & $-8,53$ & 21,53 &, 5383 &, 28462 & 4,14418 & 17,174 \\
Valid N & 212 & & & & & & & \\
(listwise) & & & & & & & & \\
\hline
\end{tabular}

Source: Processed from data

The first is the Altman model shows the average score of a potential bankruptcy at 1.0726 , while the lowest was 0.00 and the highest was 9.97, with 
a range that is large enough numbers of 9.97 and a standard deviation of 0.97 . The second models Springate shows the average score of a potential bankruptcy at 0.5856 , with a maximum value 11.41 and a minimum -27.52 and the range of 38.93 with a standard deviation of 2.597. While the third is Zmijewski figures, show the average score of a potential bankruptcy at 0.5383 with a minimum value of -8.53 and its highest value was 21.53 and 30.06 as well as a range of values with standard deviation of 4.14 .

\section{Bankruptcy Prediction Model}

The analysis to the error level of 3 prediction model of potential bankruptcy used to investigate the two categories (Sharia and Non_Sharia) can be identified as follows:

Table 5-Error level of prediction Mean Square Error (MSE)

\begin{tabular}{|c|c|c|c|c|c|c|c|c|c|c|}
\hline \multirow[b]{2}{*}{ NO } & \multirow[b]{2}{*}{ METHODS } & \multicolumn{2}{|c|}{ BANKRUPT } & \multicolumn{2}{|c|}{ SUCCES } & \multirow[b]{2}{*}{2010} & \multirow[b]{2}{*}{2011} & \multicolumn{2}{|l|}{ MSE } & \multirow[b]{2}{*}{2014} \\
\hline & & FRQ & $\%$ & FRQ & $\%$ & & & 2012 & 2013 & \\
\hline \multirow{3}{*}{ Sharia } & ALTMAN & 392 & 85,59 & 66 & 14,41 & 9,02 & 0,55 & 0,71 & 1,44 & 0,67 \\
\hline & SPRINGATE & 154 & 33,62 & 304 & 66,38 & 1,70 & 0,95 & 0,94 & 3,92 & 1,33 \\
\hline & ZMIJEWSKI & 18 & 3,93 & 440 & 96,07 & 1,08 & 1,06 & 1,62 & 2,76 & 1,72 \\
\hline \multirow{3}{*}{$\begin{array}{l}\text { Non_ } \\
\text { Sharia }\end{array}$} & ALTMAN & 182 & 85,85 & 30 & 14,15 & 0,97 & 1,40 & 0,67 & 1,05 & 0,75 \\
\hline & SPRINGATE & 127 & 59,91 & 85 & 40,09 & 3,91 & 2,05 & 2,52 & 4,48 & 1,28 \\
\hline & ZMIJEWSKI & 83 & 39,15 & 129 & 60,85 & 3,58 & 3,83 & 4,64 & 4,50 & 4,05 \\
\hline
\end{tabular}

Sources: Processed from data

Based on Table 5, can be seen that the smallest error of prediction is the sharia group, from 2010 until 2014 was a Altman model, only once it is larger in 2010 with a magnitude of 9.02 , while for the years 2011 through to 2014 all of Altman model figure lower compared with the MSE of other models. While for non_sharia can be observed that the Altman, during the observation period 2010 to 2014 always shows the lower number of MSE, thus it can be said that this approach is statistically provide stability prediction of potential bankruptcy better for both companies. 


\section{Analysis result for sharia}

To answer the second research question, wether that the average potential bankruptcy for group of sharia lower than non_sharia. It can be found that the potential bankruptcy of the non_sharia have an average of $85.85 \%$, while the sharia is $85.59 \%$. Statistically Altman method be able to show the difference level of potential bankruptcy of sharia lower than non_sharia, however, to ensure it difference, it is necessary to test. Based on t test could be explain that $t$ calculated $>t$ table or 2,04>1.196, then the position of calculated $t$ is in the rejection area. It's then, the average of $X_{1}$ is not equal to the average of $X_{2}$. Statistically there is a significant difference between the average of $X_{1}$ and $X_{2}$. Thus it can be said that statistically there's enough evidence that the intensity of the potential bankruptcy of a sharia significantly different to non_sharia. In other words, referring to the magnitude of the potential bankruptcy found that the intensity of the potential bankruptcy of a sharia group is smaller than the non_sharia.

In this section analyze some of factors that affect the predicted Altman Z-Score, for the sharia and non-sharia. The factors may affect the predicted Altman Z-Score are: 1). Macroeconomic conditions proxy for the rate of inflation (INFLA), the rupiah exchange rate against the US dollar (EXCHANGE) and the interest rate of Bank Indonesia (BIRATE); 2). Corporate governance mechanism proxy for institutional owneship (INWN), independent board (BINDT) and board size (BSIZE).

The data collected were obtained 458 pairs of the enterprise data, and to obtain the normality then we eliminated of 316 data pairs. So the amount of data analyzed were 142 pairs of the enterprise data. Furthermore, to get a research model that has better goodness of fit, then BIRATE placed as an intervening variable in effect EXCHANGE INFLA and the Altman Z-Score. Summary of the results of data analysis that be processed by AMOS expressed as follows.

Figure 1 The result of Empirical Research Model for Sharia group

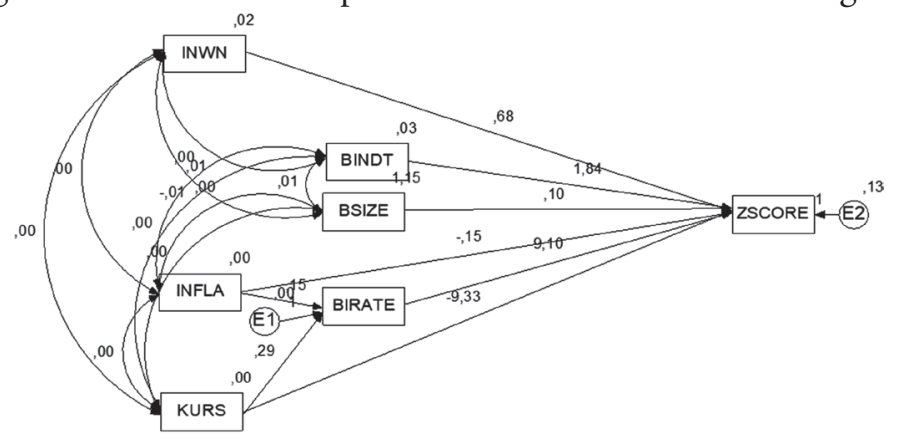

Source: Processed from data used to Amos program 
Based on the path analysis results are presented in Figure 1, show that coefficients and the direction of causal relationships among variables, then compiled two structural equation as follows:

$$
\begin{aligned}
& \text { BIRATE }=+0,150 \text { INFLA }+0,290 \text { KURS }+\varepsilon_{1} \ldots \ldots \ldots \ldots \ldots \ldots . . . . .(6) \\
& P \text { (sig-t) } \quad(0,000) \quad(0,000) \\
& \text { Z-SCORE }=+0,681 \mathrm{INWN}+1,839 \text { BINDT }+0,099 \mathrm{BSIZE} \\
& P \text { (sig-t) } \quad(0,000) \quad(0,000) \quad(0,000) \\
& -0,146 \text { INFLA }-9,334 \text { KURS + 9,103 BIRATE }+\varepsilon \\
& P \text { (sig-t) } \quad(0,946) \quad(0,008) \quad(0,124)
\end{aligned}
$$

Effects of macro-economic, proxy for the rate of inflation (INFLA) and the rupiah (RATE) to the interest rate of Bank Indonesia (BIRATE) contained in equation (6), is not discussed. The causality analysis are made to developed a goodness of fit model. Assessment of the effect Corporate Governance mechanism (institutional ownership; independent board; board size) and the Macroeconomics (which is a proxy variable inflation, the exchange rate; the interest rate of Bank Indonesia) on Potential Bankruptcy of Altman Z-Score, indicated in equation (2), with the following explanation:

Institutional ownership (INWN) has positive effect (coefficient of 0.681) and significant (level of significance of 0.000 ) against the value of Altman Z-Score. This indicates that the greater the proportion of share ownership by other institutions, would be more secure the company against the threat of bankruptcy. An independent board (BINDT) has positive effect (coefficient of 1.839) and significant (level of significance of 0.000) against the Altman Z-Score. This indicates that the greater the proportion of independent board members of the company, will be more secure against the threat of bankruptcy. The board size (BSIZE) has positive effect (coefficient of 0.099) and significant (level of significance of 0.000) against the Altman Z-Score. The condition shows that the larger the board size of directors, will be more secure against the threat of bankruptcy.

The rate of inflation (INFLA) has no effect (coefficient of -0.146 and a level of significance of 0.946 ) against the Altman Z-Score. This indicate the high and low levels of inflation has not effects to the sharia manufacturing companies group in Indonesia Stock Exchange. The value of the rupiah against the US dollar (RATE) has negative effect (coefficient of -9.334) and significantly (level of significance of 0.008) against the Altman Z-Score. This indicates that the weakening of rupiah against the US Dollars, would be the greater to threat of bankruptcy for a sharia group. The interest rate of Bank Indonesia (BIRATE) has no effect (coefficient of 9.103 and a level of significance of 0.946) against the Altman Z-Score (Z-SCORE). 
This indicates that the level of the interest rate of Bank Indonesia does not pose a threat of bankruptcy for sharia group.

\section{Analysis result for non_sharia}

The data collected were obtained 212 pairs of the enterprise data, and to obtain the normality then cuting some data until to reach the amount of 127 data pairs were eliminated. So the amount of data being analyzed is 85 pairs of the company's data. Furthermore, to get a research model that has better of goodness of fit, then BIRATE placed as an intervening variable in effect EXCHANGE INFLA and the Altman Z-Score. Summary of the results of data analysis expressed as follows.

Figure 2 The result of Empirical Research Model for non_sharia group

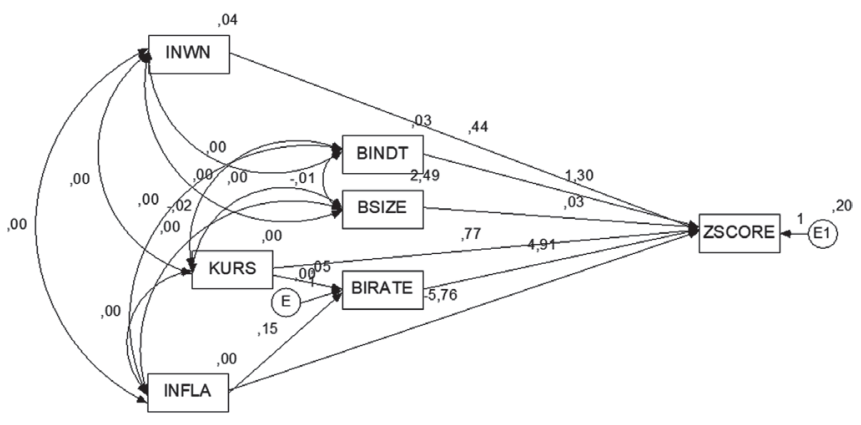

Source: Processed from data used to Amos program

Based on the path analysis results are presented in Figure 2, includes coefficients and the direction of causal relationships among variables, then compiled two structural equation as follows:

$$
\begin{aligned}
& \text { BIRATE }=+0,048 \text { INFLA }+0,148 \text { KURS }+\varepsilon \\
& P \text { (sig-t) } \quad(0,045) \quad(0,000) \\
& \text { Z-SCORE }=+1,295 \mathrm{INWN}+\text { 0,026 BINDT + 4,913 BSIZE } \\
& P \text { (sig-t) (0,000) (0,416) (0,635) } \\
& +0,443 \mathrm{INFLA}-5,763 \mathrm{KURS}+0,773 \mathrm{BIRATE}+\varepsilon_{2} \\
& P \text { (sig-t) (0,086) (0,080) (0,743) }
\end{aligned}
$$

Results of testing the effects of macro-economic conditions proxy for the rate of inflation (INFLA) and the rupiah (RATE) to the interest rate of Bank Indonesia (BIRATE) contained in equation (3), not discussed. The causality analysis are made to developed a goodness of fit model. Assessment of the effect 
mechanism of Corporate Governance (the proxy variable institutional ownership; board independent; board size) and the condition of Macroeconomics (which is a proxy variable inflation, the exchange rate; the interest rate of Bank Indonesia) on Potential Bankruptcy (which diprosi variable Z-SCORE) indicated in equation (4), with the following description:

The analysis shows that institutional ownership (INWN) has positive effect (coefficient of 1.295) and significant (level of significance of 0.000) against the Altman Z-Score. This indicates that the greater the proportion of share ownership by other institutions, will be more secure the company against the threat of bankruptcy. Independent board (BINDT) has no effect (coefficient of 0.026 and a level of significance of 0.416 ) against the Altman Z-Score. This indicates high or low proportion of independent board members have not made stronger or weaker for the Non_Sharia manufacturing company group. Board size (BSIZE) has no effect (coefficient of 4.913 and a level of significance of 0.635 ) against the Altman Z-Score. The condition shows that the board size does not make stronger or weaker for the non-sharia manufacturing company group.

Inflation (INFLA) has positive effect (coefficient of 0.443 and 0.086 of level of significance) to the Altman $Z_{-}$score. This condition shows that the higher the inflation rate will be the greater the value of Altman Z-Score, but not significantly. The value of the rupiah against the US dollar (RATE) has negative effect (coefficient of -5.763) but not significant (level of significance of 0.080). Interest rate of Bank Indonesia (BIRATE) has no effect (coefficient of 0.773 ) but not significant (level of significance of 0.743 ) against the value of Altman Z_score.

\section{Discussion}

The results of the analysis reveal that the most accurate method of predicting bankruptcy is the Altman model, these findings theoretically support the model, which is specifically modeled for analyzing manufacturing firms. Statistically the Altman model can prove that the potential bankruptcy of a sharia group is smaller than non-sharia. The analysis result on the relationship between Altman model and corporate good governance, it can be found that the potential of bankruptcy for sharia companies is influenced positive and significantly by good corporate governance (GCG) which are three factors that include; institutional ownership, the proportion of independent directors and the size of board directors. This condition indicates that increase of these indicators will be more secure sharia companies from the threat of potential financial difficulties or bankruptcy. These components of GCG reflect that the company has basic principles related to transparent, controlled, 
responsible, independent and fair. This means that the group of sharia companies has a conducive character in supporting the achievement of corporate performance as exposed by Damodaran that among the factors that affect the financial difficulties for the company is the amount of debt, due to the necessity to cover the operating costs of the company in the form of paying interest periodically and pay the principal (Damodaran, 2011). As in Sharia provisions that the company of this group is not allowed to make any debt which is riba, but permitted funding that is capital participation. While the non-sharia group is generally obtained fund from the debt of riba (DSN No.40 / DSN-MUI / X / 2003, point 3) or (QS 3, 3).

While from the macro aspect can be identified that the only exchange rate of rupiah against the US-dollar has a negative and significant effect to the bankruptcy of sharia groups. It shows that if rupiah against the US-dollar depreciated, then would be the smaller index of bankruptcy and vice versa. It means that, if rupiah against the US-dollar depreciated, then the higher the threat of bankruptcy for the sharia companies and vice versa. The sharia will be in financial difficulties at the time of rupiah against the US dollar be depreciated. The condition will then cause decrease in sales volume, which tends to decrease the revenue and profit of the company, then lead the companies are insufficient revenues to cover operating costs caused by the company activities (Damodaran, 2011).

Based on analysis to non-sharia companies, it shows that the only macro factor that has effect to the potential of bankruptcy. This factor has a positive and significant effect on the potential bankruptcy. The finding suggest that an increase in institutional ownership will have an impact on higher security of the potential bankruptcy or financial distress. This is relevant to what Brigham said that financial difficulties can be caused by a series of failed decisions and lack of control to the financial management (Brigham and Daves, 2003). Institutional ownership appears to be able to improve control of financial management, so that the company can avoid a continuous decline in financial conditions (Ghost, 2013).

\section{Conclusion}

Based on the research question could be expressed that the most accurate model used in this analysis is Altman z_score model, and by using the accurate model we find statistically significant that sharia companies have lower potential bankcruptcy than non sharia.

There are three factors of good corporate governance mechanism that have positive and significant effect to the prediction of potential bankruptcy for a sharia group, those are institutional ownership, the proportion of independent board members and size of the board directors. This indicates that statistically greater 
of institutions ownership, the higher proportion of the independent member of directors and the increasing of the size board directors will have an impact on the higher level of companies security againt to the potential bankruptcy.

This will have implications for the management of sharia_based companies, where normatively the sharia business group will provide resilience to both global and regional economic shocks, as these efforts are normatively supervised by the system inherently.

While the macro factors that affect only the rupiah against the US dollar, which shows a negative and significant relationship. It means that the potential bankruptcy of the sharia will increase when the exchange rate of rupiah to US dollar was depreciated. This condition indicates that if the value of the rupiah fell against the US dollar, the company group sharia tend to be in the financial difficulties. These findings have implications for the management of sharia_based businesses, ie management must anticipate the possibility of depreciation of the rupiah against the US dollar by hedging in order to sales revenue does not decrease, so that the revenue earned can still cover the operational costs of the company.

The potential bankruptcy of non sharia companies were only statistically positive and significantly influenced by the level of institutional ownership. It means that non sharia will be save from the threat of potential bankruptcy when institutional ownership increases. It shows that institutional ownership can increase in line to the business transfarrence for management. This has implications for business management that non-sharia business is very conducive if its management involves institutional oversight.

\section{References}

Altman, E. I. (1968). Financial ratios, discriminant analysis and the prediction of corporate bankrupcy. The Journal of Finance, 23(4), 589-609.

Argüden, Y. (2013). A Corporate Governance Model: Building Responsible Boards and Sustainable Business. Private Sector Opinion - Issue 17, A Global Corporate Governance Forum Publication.

Damodaran, A. (2011). Corporate Finance Theory and Practice (2nd ed). New York: John Wiley \& Sons Inc.

Darsono \& Ashari. (2005). Pedoman Praktis Memahami laporan Keuangan. Yogyakarta: Andi Publisher.

Elmabrok, A.A. et.al.. (2012). Using Altman's Model and Current Ratio to Assess the Financial Status of Companies Quoted In the Malaysian Stock Exchange, International Journal of Scientific and Research Publications, 2(7): 1-11. 
Fatmawati, M. (2012). Aplication of The Zmijewski Model, The Altman Model, and The Springate Model for delisting predictor. Economic Faculty Metro Muhammadiyah University, Lampung. Jurnal Keuangan dan Bank, 16(1): 56-65.

Fachrudin. (2008): Some Indication of Liquidated Bank: Warning for Customers and Investors. Professorship Inaugural Speech. Economic Faculty, Sumatra Utara University, Medan.

Ghosh, P. (2013). Testing of Altman's Z - Score model, a Case Study of Dunlop India Ltd. Paripex-Indian, Faculty,Department of Business Administration, George College of Management and Science, Kolkata, Journal Of Research 3(4): 219-220.

Glezakos, M. et.al. (2010). An Empirical Research on Early Bankruptcy Forecasting Models: Does Logit Analysis Enhance Business Failure Predictability. European Journal of Finance and Banking Research, Vol. 3 (3): 1-15.

Haber J.R. (2005). Assessing Bankruptcy Prediction Models are Evaluated. Journal of Business \& Economics Research, vol. 3 (1): 87-100.

Hadi, S. \& A. Anggraeni. (2008). Pemilihan Prediktor Delistik Terbaik (Perbandingan Antara The Zmijewski Model, The Altman Model, dan The Springate Model). Jurnal Akuntansi dan Auditing Indonesia, 12 (2): 1-9.

Abdullah, N.A.H. et.al. (2008). Predicting Corporate Failure of Malaysia's Listed Companies: Comparing Multiple Discriminant Analysis, Logistic Regression and the Hazard Model. International Research Journal of Finance and Economics, 15: 201-217.

Imanzadeh, P. et.al.. (2011). A Study of the Application of Springate and Zmijewski Bankruptcy Prediction Models in Firms Accepted in Tehran Stock Exchange. Australian Journal of Basic and Applied Sciences, 5(11): 1546-1550.

Kewal. S.S. (2012). Influence of Inflation, Interest Rate, Exchange Rate and GDP Growth on Composite Stock Price Index, Jurnal Economia, Volume 8, Nomor 1: 53-64.

Li, J.F. (2012). Prediction of Corporate Bankruptcy from 2008 Through 2011. Journal of Accounting and Finance 12(1): 31-41.

Paranowo, K. (2010). Determinant of Corporate Financial Distress in an Emerging Market Economy: Empirical Evidence from the Indonesian Stock Exchange 2004-2008. International Research Journal of Finance and Economics, 52: 80-88.

Wang, Y. \& M. Campbell. (2010). Financial Ratios and the Prediction of Bankruptcy: The Ohlson Model Applied to Chinese Publicly Traded Companies. The Journal of Organizational Leadership and Business, 17(1): 1-15. 
Salehi, M. \& B. Abedini. (2009). Financial Distress Prediction in Emerging Market: Empirical Evidences from Iran. Business Intelligence Journal, Vol 2 (2): 398-409.

Salvatore, D. (2005). Managerial Economics In a Global Economy. 5th edition.Ohio: Thompson, South-Western.

Titman, S., \& C.T. Opler. (1994). Financial Distress and Corporate Performance. The Journal of Finance, 49 (1): 1015-1040.

Veronica, M. et.al. (2014). Bankruptcy Prediction Model: An Industrial Study In Indonesian Publicly-Listed Firms During 1999-2010. Society of Interdisciplinary Business Research \& Universiti Kuala Lumpur Business School, Malaysia, February 7-8.

Zmijewski, M.E. (1984), "Methodological Issues Related to the Estimation of Financial Distress Prediction Models" Journal of Accounting Research 22 (Suppl.): 59-86. 